\title{
Ordens religiosas e transgressão no Maranhão colonial ${ }^{1}$
}

\author{
Pollyanna Gouveia Mendonça²
}

As mais diferentes ordens religiosas desempenharam papel fundamental desde o início da ocupação do território do Maranhão. O seu estudo, entretanto, é um tema pouco discutido. Este artigo pretende colaborar com essa questão, analisando os maus comportamentos e as transgressões cometidas por alguns membros do clero regular no Maranhão colonial, utilizando como fontes os processos do Tribunal Episcopal e do Conselho Ultramarino. Palavras-chave: ordens religiosas, transgressão, Maranhão colonial.

\section{Religious orders and transgression in colonial Maranhão}

The most different religious orders played vital role since the beginning of the occupation of territory of Maranhão. The study, however, is a subject little discussed. This article intends to collaborate with this question by analyzing the bad behaviors and the transgressions committed by some members of the regular clergy in colonial Maranhão, using as sources the Episcopal Court and Overseas Council processes.

Keywords: religious orders, transgression, colonial Maranhão.

\section{Religieux d'ordonnances et transgression en Maranhão colonial}

Les plus différents ordres religieux jouent le rôle vital depuis le début de l'occupation en l'isle de Maranhão. Létude, cependant, est un sujet peu discuté. Cet article a l'intention de collaborer avec cette question en analysant les comportements mauvaises et les transgressions commises par certains membres du clergé régulier au Maranhão colonial, en utilisant comme sources des processus de Cour épiscopale et des outre-mer Conseil. Mots-clés: ordres religieux, transgression, Maranhão colonial.

\footnotetext{
${ }^{1}$ Artigo recebido em 9/6/2011 e aprovado para publicação em 15/9/2011.

${ }^{2}$ Doutora em História pela Universidade Federal Fluminense e professora da Universidade Federal do Maranhão, campus de Pinheiro.E-mail: pollyannagm@yahoo.com.br
} 


\section{Preâmbulo}

A história eclesiástica do Maranhão está ainda por ser escrita. Poucas, mas importantes, obras ${ }^{3}$ servem de suporte às pesquisas, mas nada tem sido escrito nas últimas quatro décadas sobre a história institucional da Igreja do Maranhão no século XVIII. A maior parte das obras sobre esse tema foi produzida por eclesiásticos, e disso decorre uma série de interpretações muito brandas do comportamento do clero local, bem como narrativas deveras apologéticas e muitas vezes acríticas quanto ao trabalho missionário que foi feito naquelas terras. Tais obras se detêm longamente na descrição dos personagens das altas hierarquias do clero, notadamente os bispos. É notória a escassez de fontes especialmente no que diz respeito às ordens religiosas. Esse é, pois, um terreno praticamente inexplorado.

As obras de referência sobre a Igreja no Maranhão, dentre elas a de D. Francisco de Paula e Silva, Apontamentos para a história eclesiástica do Maranhão; a de D. Felipe Conduru Pachecho, A história eclesiástica do Maranhão; e, finalmente, a de Mário Meireles, História da arquidiocese de São Luís, apenas descrevem a chegada das ordens religiosas na região, tratando de capuchos, jesuítas, carmelitas, mercedários e, posteriormente, franciscanos, que já vinham se organizando naquelas plagas desde os primórdios dos seiscentos, fundando conventos, capelas, colégios e igrejas.

Quase nada foi produzido sobre os conflitos, processos e crimes em que estiveram envolvidos os membros das mais variadas ordens religiosas. As obras que tratam dos primórdios da chegada desses religiosos ao Maranhão são os já clássicos História da missão dos padres capuchinhos na ilha do Maranhão e suas circunvizinhanças, escrita por Claude d'Abbeville, em 1614, e Viagem ao Norte do Brasil feita por Yves d'Evreux entre 1613 e 1614. ${ }^{4}$ Ambas destacam o trabalho junto aos índios, bem como aspectos da natureza, dos costumes e da geografia da terra então ocupada por franceses. No século XVIII, padre José Morais, jesu-

\footnotetext{
${ }^{3}$ SILVA, Francisco de Paula e (Dom.). Apontamentos para a história eclesiástica do Maranhão. Bahia: Tipografia de São Francisco, 1922; PACHECO, Felipe Condurú. História eclesiástica do Maranhão. São Luís: Senec/Departamento de Cultura, 1969; MEIRELES, Mário Martins. História da Arquidiocese de São Luís. São Luís: Universidade do Maranhão/Sioge, 1977.

${ }^{4}$ Respectivamente, D’ABBEVILLE, Claude. História da missão dos padres capuchinhos na ilha do Maranhão e suas circunvizinhanças. São Paulo: Sciliano, 2002. (Coleção Maranhão Sempre); D’EVREUX, Yves. Viagem ao Norte do Brasil: feita nos anos de 1613 a 1614. São Paulo: Sciliano, 2002. (Coleção Maranhão Sempre).
} 
íta e cronista português, escreveu a História da Companhia de Jesus na extinta província do Maranhão e Pará. ${ }^{5}$ Depois deles, há apenas os estudos já citados de Silva, Pacheco e Meireles ${ }^{6}$ e, mais recentemente, apenas o trabalho de Sebastião Cavalcanti, também sobre a presença dos jesuítas na região. ${ }^{7}$

O objeto desta investigação é, pois, inédito. Objetiva-se, aqui, introduzir esse assunto e apontar caminhos de investigação sobre as transgressões cometidas por membros de ordens religiosas, a relação desses religiosos com as autoridades do Maranhão, sejam elas seculares, como os governadores, sejam elas eclesiásticas, como os prelados e os vigários-gerais. Tratarei aqui, também, de como esses processos eram julgados, quais as penas aplicadas a esses religiosos e como os seus superiores lidavam com as transgressões dentro de seus conventos. A escassez de fontes é, como já apontei, um obstáculo. Afinal, os documentos pertencentes a cada uma dessas ordens, se ainda existem, não são liberados para consulta. Desta feita, só se pode conhecer um pouco da história de transgressão dos religiosos do bispado do Maranhão a partir da documentação do Conselho Ultramarino, de alguns processos pertencentes ao acervo do Juízo Eclesiástico do Maranhão ${ }^{8}$ e de denúncias e processos da Inquisição de Lisboa. ${ }^{9}$

\footnotetext{
${ }^{5}$ MORAIS, José de (Pe.). História da Companhia de Jesus na extinta província do Maranhão e Pará. Rio de Janeiro: Alhambra, 1987 [1759]

Na mesma linha dessa obra, do padre José de Morais, temos ainda as obras de Serafim Leite e Felipe Bettendorf. LEITE, Serafim. Luiz Figueira. A sua vida heroica e a sua obra literária. Lisboa: Agência Geral das Colônias, 1940 e BETTENDORF, João Felipe. Crônica dos Padres da Companhia de Jesus no Estado do Maranhão [1698]. 2 ed. Belém: Secretaria de Estado da Cultura, 1990.

${ }^{6}$ SILVA, 1922; PACHECO, 1969; e MEIRELES, 1977.

${ }^{7}$ CAVALCANTI, Sebastião. A questão jesuítica no Maranhão colonial (1622-1759). São Luís: Sioge, 1990.

${ }^{8}$ O Tribunal Eclesiástico ou Auditório Eclesiástico era o juízo de alçada dos bispos em que poderiam ser julgados indivíduos de acordo com a pessoa, notadamente eclesiásticos, ou com a matéria dos delitos, não importando, assim, quem os tivesse cometido. Dessa feita, leigos e clérigos poderiam ser processados e punidos no tribunal episcopal. Parochos imperfeitos: justiça eclesiástica e desvios do clero no Maranhão colonial. Tese (Doutorado) - Universidade Federal Fluminense, Instituto de Ciências Humanas e Filosofia, Rio de Janeiro, 2011.

${ }^{9}$ Essa temática apareceu nas minhas pesquisas quando tratava das questões de alçada do Juízo Eclesiástico. O bispo não tinha poder para julgar membros do clero regular, mas isso não significava que suas transgressões não fossem registradas por outras autoridades. Na ausência de um acervo específico que tratasse desses membros do clero, passei a investigar o que havia sobre eles em outros fundos, tais como o Arquivo Histórico Ultramarino e a Inquisição de Lisboa.
} 


\section{Notas sobre o clero regular no Maranhão}

D. Francisco de Paula e Silva afirma que a história eclesiástica do Maranhão teria começado mesmo com a chegada de ordens religiosas. Segundo ele, tudo começou "com os Capuchinhos Frei Ivo d'Evreux, Frei Arsenio de Pariz e Frei Ambrosio de Amiens, que vieram para o Maranhão com Frei Claudio de Abbeville, pelos annos de 1612". Há, ainda, quem prefira "datal-a de 1607 (20 de Janeiro) quando de Pernambuco partiram os Padres Jesuitas para abrir caminho á conquista do Maranhão". ${ }^{10}$

À época da fundação do bispado, contava São Luís com uma população de dois mil fiéis, uma igreja matriz que passou a ser a catedral, um colégio e igreja dos jesuítas e uma igreja e convento dos franciscanos. Eis tudo. A cidade crescia "mal alinhada, com ruas estreitas e uma população mesclada de raros nobres, gente de guerra, colonos portugueses, aventureiros de todas as espécies e cablocos mal ageitados". ${ }^{11}$ No Natal do ano 1612, os capuchinhos inauguraram a capela de São Francisco e ao lado dessa igreja começaram a construção do convento que lhes serviria de abrigo. ${ }^{12}$ Quando, em 1615, foram expulsos os franceses, os capuchinhos entregaram sua residência a dois franciscanos portugueses que vieram de Pernambuco, frei Cosme de São Damião e frei Manoel da Piedade. ${ }^{13}$

Os carmelitas também vieram na missão de reconquista portuguesa do Maranhão. Receberam da Coroa portuguesa a doação da ilha do Medo e mais duas léguas de terra em São Luís. Foram os primeiros a fundar um convento dentro dos limites da cidade, em 1616. Em 1645, fundaram outro em Alcântara e, em 1718, um hospício na ponta do Bonfim. ${ }^{14} \mathrm{O}$ convento do Carmo Novo, segundo Mário Meireles, "famoso se fez, também, desde o início, pelas aulas de latim e de música que nele seriam ministradas aos filhos dos colonos", e ainda pelo "o curso de noviciado", que "foi de tal qualidade que já em 1727 era autorizado, pelo Papa Bento XIII (1724-1730), a conceder título de Doutor aos que nele se graduassem em Teologia. ${ }^{15}$ Os carmelitas formavam uma vigairaria cuja jurisdição abrangia

\footnotetext{
${ }^{10}$ SILVA, 1922, p. 11.

${ }^{11}$ SILVA, 1922, p. 68.

${ }^{12} \mathrm{Id}$.

${ }^{13} I d$.

${ }^{14} I d .$, p. 17.

${ }^{15}$ MEIRELES, 1977, p. 32.
} 
até os conventos do Pará. Todos eles, entretanto, dependiam dos Superiores da Província de Lisboa. ${ }^{16}$

Outros que vieram na expedição de reconquista do Maranhão por Portugal foram os jesuítas. Fundaram sua primeira missão "em Açagoába, hoje Vinhais, onde, com os da ilha, aldearam os índios que tinham trazido de Pernambuco". ${ }^{17}$ Em 1622, chegaram às terras maranhenses os jesuítas Benedito Amodeo e Luiz Figueira. Antonio Moniz Barreiros, então nomeado capitão-mor do Maranhão, conta que logo que aqui desembarcaram os jesuítas "entrou logo o povo a inquietar-se e a intentar pelos meios mais violentos a retirada dos novos missionários no mesmo barco em que vieram de Pernambuco". Tudo ocorria, segundo ele, pela "sua ambição no captiveiro dos desgraçados índios". ${ }^{18}$ As relações entre o povo do Maranhão e os padres da Companhia de Jesus foram sempre muito conflituosas, mas não é esse o objeto da investigação em curso.

Os mercedários entraram no Maranhão provavelmente no ano 1734. Quatro membros dessa ordem vieram, mas pouco edificaram, segundo a historiografia local. Fundaram um convento no Pará no ano 1640 e dois no Maranhão, um em São Luís, em 1654, e um em Alcântara, em 1659. Em 1654, iniciaram no Desterro a construção "mais ampla e já de pedra e cal, de sua igreja e Convento de Nossa Senhora das Mercês". ${ }^{19}$ Tais religiosos dependiam diretamente da Coroa espanhola.

Desde 1636, o padre Luís Figueira já destacava a necessidade de se criar um bispado ou prelazia no Maranhão. Em 1653, o padre Antonio Vieira reafirmava tal necessidade, o que não se efetivaria no reinado de D. João IV. Só em 30 de agosto de 1677, pela bula Super Universas Orbis Ecclesias, do papa Inocêncio XI, que seria criado o bispado do Maranhão. Longo território, estendia-se, segundo D. Francisco de Paula e Silva, "para o Sul até a Capital do Ceará, exclusive; pelo Norte até o cabo do norte, e pelo Sul até as colônias hespanholas". No reinado de D. João V, "os limites do Estado do Maranhão como os do Brazil, foram restringidos do cabo de S. Roque à Serra de Ibiapaba até o mar $32^{\circ} 15^{\prime}$ de latitude

\footnotetext{
${ }^{16}$ SILVA, 1922, p. 17.

${ }^{17}$ MEIRELES, 1977, p. 19.

${ }^{18}$ Apud SILVA, 1922, p. 30.

${ }^{19}$ MEIRELES, 1977, p. 33.
} 
austral". ${ }^{20}$ Área ampla, o que não era peculiaridade alguma ao novo bispado, mas que desde logo precisaria de gente para ocupar e religiosos para ensinar a doutrina e catequizar os índios. Os conventos que fundamentavam a criação da diocese eram quatro:

O de Nossa Senhora da Luz, Colégio dos Jesuítas, no recinto amurado; o de Nossa Senhora do Carmo, dos Carmelitas Calçados, já fora dos muros e no centro da cidade; o de Santo Antonio [...], nos confins do bairro novo, quase às margens do Maioba; e o da Nossa Senhora das Mercês dos Mercedários, na extremidade do bairro velho, à margem do Bacanga. ${ }^{21}$

Importantes personagens na ocupação do Maranhão e na catequização dos índios, esses religiosos não ficaram isentos de vigilância e nem de tentativas de punições se procedessem mal. Convém investigar agora a que jurisdição pertenciam esses casos, como esses religiosos eram processados e quais as punições reais que recebiam. Inicio pela relação das ordens religiosas com o bispo.

\section{O clero regular sob jurisdição do bispo?}

Poucos foram os frades processados no Tribunal Episcopal do Maranhão, ou seja, no tribunal dos bispos. Isso se explica porque os regulares estavam sujeitos diretamente ao superior do seu cenóbio e, em segunda instância, ao provincial da sua ordem. ${ }^{22}$ Apenas quatro em um universo de 429 processos ${ }^{23}$ pertencentes ao acervo eclesiástico do Maranhão são contra membros do clero regular. O que não quer dizer que os religiosos não transgredissem, como será aqui demonstrado.

O direito de julgar clérigos regulares e leigos era assunto que motivava grandes discussões sobre até onde iriam as competências do juízo eclesiástico. No que

\footnotetext{
${ }^{20} I d$., p. 56.

${ }^{21}$ MEIRELES, p. 62.

${ }^{22}$ GOUVEIA, Jaime Ricardo. Quod non est in actis, non est in mundo: mecanismos de disciplina interna e externa no Auditório Eclesiástico de Coimbra. Revista de História da Sociedade e da Cultura, n. 9, p. 186, 2009.

${ }^{23}$ Destes, 254 são processos contra leigos e 170 contra padres seculares, os clérigos de missa que estavam mais diretamente envolvidos com a população. Há ainda os quatro processos contra clérigos regulares, os que pertenciam a ordens religiosas e um processo contra o Cabido da Sé do Maranhão, que era o colégio de clérigos que auxiliavam o bispo no governo da diocese. MENDONÇA, 2011, p. 74.
} 
diz respeito ao clero regular, o manuscrito anônimo intitulado Memória ${ }^{24}$ possibilita conhecer detalhes de como foram complexas as discussões que reduziram paulatinamente o poder dos prelados sobre o clero regular. Em uma das suas passagens consta que

Do sexto século por diante entrarão a conceder-se alguns privilégios aos Regulares; este privilégios porém athé o século 11, e 12 limitavão se somente a couzas temporaes, como a livre deposição de seus bens, a elleição de seus Abades, a izenção de certos direitos, e encargos, que os Bispos pertendião imporlhes, tudo afim de favorecer a paz e a tranqüilidade dos mesmos Regulares, e não a izentallos da jurisdicção Canonica dos Bispos nas funções Hierarquicas, na correção dos excessos dos mesmos regulares e seus Abades, de maneira que taes privilégios não podem denominarse verdadeiras izenções, pois que para alguns delles concorrerão com o seu consentimento os mesmos Bispos. ${ }^{25}$

Então, de certo modo, os regulares estiveram sujeitos ao controle de seus excessos e, em certa medida, sujeitos ao juízo do prelado. O cenário sofreu alteração, segundo o autor anônimo, a partir dos séculos XI e XII, quando os privilégios dos regulares começaram a se expandir e iniciaram-se "izenções sem número e sem limite, muito principalmente no tempo do Sysma, que principiou na morte de Gregório 11". ${ }^{26}$ Isenções essas que o Concílio de Trento não conseguiu abolir, mas apenas modificar algumas. Esse mesmo autor demonstra o conflito durante o Concílio, ao afirmar:

Entrandose porem a tratar da matéria, os Geraes e todos os Theologos se amotinarão; os Prelados, porque lhes era muito custozo renunciar a huma authoridade, de que desde longo tempo se achavão de posse; os inferiores porque lhes era duro sujeitarem se a huma authoridade que não julgavão tão indulgente, como os seus superiores domésticos. Recorrerão aos Embaixadores de alguns Principes, os quês tomarão o seu partido; por outra parte os delegados do Pontífice apoiando estas izenções pelo conhecido interesse da sua Corte; fizerão que os Bispos Alemães e outros empenha-

\footnotetext{
${ }^{24}$ Esse manuscrito pertence ao acervo do Patriarcado de Lisboa e não está numerado, assim como os demais dessa série. É possível conhecer apenas a caixa e o número dos maços, todos eles referentes ao século XVIII. Arquivo Nacional da Torre do Tombo, Patriarcado de Lisboa, Papéis Diversos, caixa 72 , maço 22 , documento sem numeração.

${ }^{25} \mathrm{Id}$.

${ }^{26}$ Ibid.
} 
dos na abolição afrouxassem nas suas pretenções, e prevalecesse as dos Bispos Franceses, que queriam somente modificações. ${ }^{27}$

O autor encerra seus comentários afirmando que não só a Igreja pretendia restaurar toda a antiga subordinação dos regulares ao bispo, bem como vários soberanos agiam no mesmo sentido como fiéis protetores da mesma Igreja. O cerne da questão estava no fato de que o clero regular estava sujeito às regras da sua ordem religiosa, ou seja, deviam obedecer diretamente aos seus superiores nos mosteiros e conventos, e, portanto, tinham seus próprios meios de julgar os desviantes sem que para isso precisassem da interferência do Tribunal Episcopal.

Os bispos, entretanto, não deixaram de vigiar o mau comportamento dos clérigos regulares. Exemplo disso é um ofício do ano 1764 em que o bispo D. frei Antonio de S. José escreveu a Francisco Xavier de Mendonça Furtado, secretário de Estado da Marinha e Ultramar, relatando o mau comportamento de dois frades: frei Bernardo de Santo Elias e frei José Roma. Sobre o primeiro, informou que, assim que chegou ao bispado do Maranhão, "despio o habito, pondo-se em traje de secular com animo de não tornar a sua religião, plantou sua roça no Iguará e entrou nas idéias de comerciar em couros”. Sobre o segundo, disse que, fazendo uma visita aos sertões, encontrou-o fora de seu convento, vivendo como secular. Mandou ordem que os párocos do lugar não admitissem que o frade celebrasse missa e, por uma pastoral, proibiu que ele celebrasse em casas e capelas. O frade, no entanto, não obedeceu, "por que nas cazas dezia occultamente" ${ }^{28}$ Como descrito, os bispos não podiam julgar tais casos. D. frei Antonio de S. José encaminhou a denúncia à autoridade competente, o provincial dos carmelitas descalços, mas só depois de informar à autoridade régia.

O bispo em questão estava à frente da diocese desde 1756. Foi durante a sua prelazia que ocorreu a expulsão dos jesuítas do Maranhão, por meio de lei de 1759, já tendo esses religiosos sido expulsos antes, em 1661 e em 1684. Mediante

${ }^{27}$ O Concílio decidiu por três pontos: "1 que as izençoes são odiosas por serem contrarias ao dito direito comum; 2 que as intenções da Igreja tem sido constantes em abolir taes izenções, e se não tem feito he porque as poucas luzes dos tempos anteriores, as manobras e intrigas dos regulares já nas Cortes dos Principes, já na de Roma tem contrariado os ardentes votos dos Prelados mais ilustrados e Insignes em virtudes e 3 que todavia hoje se achão mui limitadas, e restrictas de maneira, que senão estendem as funções hierarquichas, e competem somente as Religiozas". Ibid.

${ }^{28}$ Arquivo Histórico Ultramarino (doravante, AHU); Conselho Ultramarino (doravante CU); Capitania do Maranhão (doravante CM), doc. 4078. 
as represálias contra os inacianos, o bispo até tentou não obedecer às determinações régias de expulsão, preferindo exilar-se da sede do bispado em direção ao interior. Esse foi um período de sérios enfrentamentos entre a autoridade eclesiástica e o governo civil. Devido a tais conflitos, D. frei Antonio foi chamado a regressar ao Reino em 1766. Por ordem do rei, viria o cônego Dr. Pedro Barboza Canaes para ficar à frente do cabido e do governo do bispado como vigário capitular. Este, porém, foi descrito pela historiografia local como "imprudente e brigão", já que "quis impor-se e malquistou-se com todo mundo". ${ }^{29}$

Não tardaram os seus conflitos com os membros das ordens religiosas. Em 1768, o prior do Convento do Carmo, frei Thomas de Santo Elias, escreveu para Francisco Xavier de Mendonça Furtado, secretário de Estado da Marinha e Ultramar, sobre o impedimento aplicado pelo referido vigário capitular em expor o Santíssimo Sacramento. O prior alega que, "desde a fundação deste convento, que passa de cento e quarenta annos, sempre se acostumou fazer a dita expozição sem licença do Ordinario" ${ }^{30}$ na festa à padroeira daquela casa do capítulo, Nossa Senhora da Piedade. Como Barbosa Canaes lhe mandou impedir apenas "por recado vocal", ele continuou "fazendo a referida expozição sem a dita licença”. O vigário capitular, então, puniu toda a ordem, mandando suspender o "poder confessar, e pregar, e ainda de poder ministrar funsão alguma Eccleziastica fora do âmbito da minha Igreja." ${ }^{31}$ Os carmelitas, então, apelaram ao poder real e recorreram ao Juízo da Coroa.

A versão do Dr. Pedro Barbosa Canaes era, no entanto, outra. Ele alegava que sua jurisdição tinha sido usurpada. O frade, por sua vez, afirmou que a decisão do governador foi arbitrária, já que ele não foi notificado de uma primeira vez, nem ouvido em audiência. Nos autos ele chega a afirmar que "ao mesmo demônio se deve dar defeza antes de ser condemnado; como sem agravo poderá o Reo Recorrente e sua comunidade ser condemnado em pena de suspenção sem lidar lugar a mostrar o seo direito?" $32 \mathrm{O}$ recurso pedia a invalidação da ordem de Pedro Barbosa Canaes e a imediata recolocação do frei no seu posto de guardião do convento.

\footnotetext{
${ }^{29}$ PACHECO, 1969, p. 59.

${ }^{30}$ AHU, CU, CM, doc. 4203.

${ }^{31} \mathrm{Id}$.

${ }^{32}$ AHU, CU, CM, doc. 4205.
} 
Frei Thomas de Santo Elias, "por cabeça de sua comunidade", pretendia "mostrar os Privilegios, Graças, e Indultos concedidos a sua comunidade de que estão de posse e o direito que lhes assiste para não serem privados de coadjutores espirituais nem terem dado motivo algum para isso". ${ }^{33}$ Pedro Barboza Canaes se defende dizendo que acreditou que, depois do recado que mandou ao frei, ele fosse lhe obedecer, mas assim não foi, e disse mais: "Bem sabe Deos e a Virgem Nossa Senhora quam violento me he este procedimento contra os filhos da Augusta May de Deos Nossa Senhora do Carmo, e por isso não chego a desembahinhar a espada da Igreja com mayor impetu e mais fortes procedimentos." ${ }^{34} \mathrm{~A}$ sentença do Juízo da Coroa foi a favor dos frades e exigia que Canaes desistisse da opressão contra esses religiosos e levantasse a suspensão.

Em defesa dos carmelitas esteve ainda o frei José Lopes da Cunha, visitador dos conventos do Carmo no Pará e Maranhão, que, em carta a Mendonça Furtado naquele mesmo ano, também defendeu a "immemorial posse" que os frades tinham de expor o Santíssimo sem licença do Ordinário. ${ }^{35} \mathrm{O}$ vigário capitular era, entretanto, reincidente. No mesmo ano 1768, frei Manoel de São Boa Ventura escreveu ao Conselho Ultramarino informando que o Dr. Pedro Barbosa Canaes também proibiu os religiosos de Santo Antônio de expor o Santíssimo. No ofício consta que esse procedimento já tinha sido considerado arbitrário pelo Tribunal da Coroa, que decidira por mandar suspender as ordens que o vigário capitular tinha dado aos religiosos carmelitas. Tais conflitos só cessaram quando o vigário capitular foi convocado a voltar ao Reino.

Do mesmo ano é o processo instaurado contra frei Francisco José dos Reis. Ele foi processado no Tribunal Episcopal acusado de, no dia 23 de fevereiro de 1768, chamar José de Arede depois da missa para uma capela chamada de Nossa Senhora do Capítulo, "descompondo-o com palavras injuriozas chamando-lhe maroto e mariola". ${ }^{36}$ Formularam acusações de sacrilégio, quatro testemunhas foram chamadas a depor e confirmaram ter presenciado a discussão. Uma das testemunhas comentou, inclusive, que o padre ainda dera um bofetão no rapaz. ${ }^{37}$

\footnotetext{
${ }^{33} I d$.

${ }^{34}$ Ibid.

${ }^{35}$ AHU, CU, CM, doc. 4206.

${ }^{36}$ Arquivo Público do Estado do Maranhão (doravante APEM), Autos Sumários, doc. 4501, fl. 1 v. ${ }^{37}$ Id., fl. 6.
} 
Nos conclusos, o vigário-geral mostrava-se incapaz de julgar o caso sentenciando, que mandava "remeter por treslado ao Reverendíssimo Vigario Provincial da Religião Carmelitana" ${ }^{38}$ para julgar o seu irmão de hábito.

Além do frei Francisco José dos Reis, outro clérigo regular esteve sob julgamento naquele tribunal. O frei Cosme Damião da Costa Medeiros, vigário-geral forense de Oeiras ${ }^{39}$ e também sentenciado na Inquisição portuguesa, ${ }^{40}$ foi processado três vezes. Em 1796, foi denunciado por vários crimes no exercício da mesma vigairaria forense $\mathrm{e}^{41} \mathrm{e}$, especialmente, porque não era considerado como o legítimo ocupante daquele cargo pelos outros párocos da região do Piauí. Em 1797, esteve entre os suspeitos de sacrilégio e roubo na Igreja de Oeiras, ${ }^{42}$ de onde ainda era pároco. Foi condenado pelo vigário-geral do Maranhão, no mesmo ano 1797, porque devia a Alexandre Rodrigues de Carvalho a quantia de 131.300 réis. $^{43}$

\section{(Des)ordens religiosas: desobediência e transgressão no Maranhão colonial}

Quando, em 1666, frei Francisco de Andrade chegou ao Maranhão, foi logo recebido com a "repugnancia dos Religiosos de N. Senhora das Merces", que não queriam aceitá-lo como seu legítimo superior. Pediu, então, ao governadorgeneral que "lhe fizesse dar toda a ajuda e favor para que fosse obedecido por Prelado maior dos ditos Religiosos na conformidade das ordens que recebeu de

\footnotetext{
${ }^{38} \mathrm{Ibid}$., fl. 7 v. zir uma fiel no confessionário; e ANTT, TSO, IL, proc. 14880, fl. 44.

${ }^{41}$ APEM, Autos e Feitos Diversos, doc. 4315.

${ }^{42}$ APEM, doc. 4507, fl. sem numeração.

${ }^{43}$ APEM, Feitos Cíveis de Assinação de Dez Dias, doc. 2607.
}

${ }^{39}$ As atribuições de vigário-geral forense eram, sem dúvida, muito mais amplas. Além de todas as competências que cabiam ao vigário de vara, que eram importantes oficiais eclesiásticos nas regiões mais afastadas dos bispados, ele poderia ainda conhecer "as causas crimes em flagrante delicto, procedendo a prisão"; "receber denunciações de peccados publicos por accusação do Promotor, ou de legitimo accusador, e dando livramento às partes"; "conceder cartas de seguro aos criminosos"; "passar cartas de excommunhão por cousas furtadas, ou perdidas"; "benzer todos os paramentos necessário ao culto divino". Regimento do Auditório Ecclesiástico do Arcebispado da Bahia, Metropoli do Brasil. São Paulo: Typographia 2 de Dezembro, 1834. Tit. X, n. 401, fl. 93.

${ }^{40}$ As acusações que pesavam contra ele eram de crime de sigilismo, porque teria revelado o segredo da confissão; de crime de solicitação, porque teria aproveitado do momento da confissão para sedu- 
Sua Santidade". ${ }^{44}$ Depois das recusas desses religiosos em aceitar sua autoridade, resolveu utilizar de censuras e proibiu os fregueses de comunicação com os frades sob pena de excomunhão.

A partir daí, grandes conflitos se seguiram. Frei Francisco, depois das reações indignadas dos frades, refugiou-se em Alcântara, mas "mandarão buscar o dito Prelado em huma canoa por alguns religiozos do mesmo habito armados, e preparados com todo o gênero de armas". Os frades teriam se utilizado de "toda a violência e sem respeito algum o troxerao prezo ao dito convento onde o meterao em hum cárcere". ${ }^{45} \mathrm{O}$ governador, então, requereu que lhes entregasse o preso e decidiu mandar por cerco ao convento "para que ao menos amedrontados com a vista das Armas, os soldados ordenassem a dita entrega". Frei João da Madre de Deus, que comandava os insurretos, "respondeu por repetidas vezes que o não havia de entregar ainda que morresse com os mais religiozos". Dizia que tinha "culpas do dito Prellado para o poder castigar, e que nem eu [governador] nem V. Magestade se podiao intrometer no governo do seu Convento" ${ }^{46} \mathrm{O}$ governador conseguiu libertar o prelado e levou-o para sua casa. Ele, então, aplicou censuras aos religiosos e o movimento foi sufocado.

Anos depois, em 1698, outro religioso das mercês iria desafiar novamente o seu prelado. Frei Matheus de Siqueira teria cometido uma série de transgressões a ponto de o ouvidor-geral, Manuel Dias da Costa, escrever ao Reino contanto os excessos do religioso, que chegou a fugir do convento. Consta na missiva que, "mandando o seu Prellado [a quem não queria conhecer por tal] buscallo por alguns seus relligiozos, se poz em fugida e se meteu no Convento do Carmo, e o Provincial se obrigou a levallo ao seu Prellado para lhe render obediencia, como legítimo que era". ${ }^{47}$ Frei Matheus teria se escondido também na igreja matriz. Frei Antonio Soares Prezentado, comissário e visitador-geral dos Conventos de Nossa Senhora das Mercês no Estado do Maranhão, contou que foi tomar posse do governo e teve notícia da fuga de frei Matheus. Este lhe teria mandado comunicar que iria para Roma tratar de assuntos do bispado em nome de D. frei Thi-

\footnotetext{
${ }^{44}$ AHU, CU, CM, doc. 515.

${ }^{45}$ Id.

${ }^{46} \mathrm{Ibid}$.

${ }^{47}$ AHU, CU, CM, doc. 972.
} 
móteo do Sacramento, quando na verdade tinha sido enviado preso para Lisboa e, de lá, seria entregue à cúria romana.

Só na centúria seguinte que novas queixas de mau comportamento do clero regular chegariam ao conhecimento das autoridades metropolitanas. Em 1734, o governador do Maranhão, José da Serra, enviou consulta ao Conselho Ultramarino sobre "escândalo e rellaxação com que a mayor parte dos missionários daquelle Estado", segundo ele, "viviam comerciando como se fossem mercadores e comettendo outras dezordens e dezatencoens indignas do Estado Relligiozo em grande desserviço de Vossa Magestade". ${ }^{48}$

O comissário provincial e superior das Missões do Pará, frei André do Rosário, escreveu, por sua vez, para reclamar "de o haver despoticamente inhibido o Governador daquelle Estado Joseph da Serra de assistir nas Juntas". Afirmava que ele teria "pouca razao para Romper naquelle excesso" 49 e pedia que o rei ordenasse ao dito governador que o reconhecesse para deputado das Juntas das Missões. Mais adiante, comenta que as missões tinham sido entregues aos capuchos e que os franciscanos

afastandose da pobreza de seo Santo Patriarcha que são obrigados por votto se tinhao feito negociantes públicos, e mercadores que os seos Prelados os tratem com rigor com que Jezus Christo lançou fora aos que estavao no Templo e que so se lembra serem frades para allegarem os seos privilégios e isencoens sendo na realidade mercantes aos quaes por nenhuma ley, ainda suppondose ecclesiasticos, são concedidas. ${ }^{50}$

Por fim, escreve que

Lhe parecia que este conselho devia fazer a Vossa Magestade regente a necessidade que há de se occorrer a estes escândalos escrevendose aos Superiorez que tem neste Reyno para que pontualmente os evitem, e que da vinha do Senhor se arraquem estas mas plantas, pondose em seo lugar outraz que produzam melhores fructos, porque $\mathrm{o}$ não fazendo assim tomaria Vossa Magestade a resollução de encarregar as Missoes a Provincia ou relligiao diversa, e a missionarios que se satisfação com as côngruas que para sua subsistência lhe dá Vossa Magestade. ${ }^{51}$

\footnotetext{
${ }^{48}$ AHU, CU, CM, doc. 2155.

${ }^{49} I d$.

${ }^{50}$ Ibid.

${ }^{51}$ bid.
} 
O procurador da Coroa foi, então, ouvido sobre a questão e disse "que se devia representar a Vossa Magestade o escândalo com que vivia estes chamados Missionarios negociando publicamente" e que se recomendasse "aos seus superiores que os mandessem logo retirar, e que quando assim o não fação o Governador os faça recolher para este Reyno nos primeiros navios que partirem daquelle Estado".52 Afirma que o frei José da Penha, enviado como reformador para o Maranhão, chegara sem autorização de Sua Majestade. Pedia, assim, que o governador o mandasse preso no primeiro navio que partisse para Lisboa. O Conselho Ultramarino, entretanto, deliberou que ele assumisse o cargo e ordenou que o governador desse o cumpra-se.

O parecer do Conselho Ultramarino deliberou, ainda, que se mandasse "recomendar ao Provincial dos capuchos da Provincia de Santo Antonio" que mandasse logo "recolher para este Reyno nos primeyros navios que vierem daquelle Estado ao Frey Andre do Rozario e ao leygo Frey Manoel da Piedade"; que o provincial "mandasse advertir aos seos subditos os escândalos que cauzam com suas desordens e negociacoens tendo entendido devem proceder como verdadeyros missionários" ${ }^{53}$ Se assim não o fizessem, Vossa Majestade poderia usar "com elles do seo Real poder, privando os das Missoes se lhes tem entregue". ${ }^{54}$

Em 1758, novas denúncias de mau comportamento de religiosos chegaram ao conhecimento do rei. O procurador-geral da vigairaria de Nossa Senhora do Monte do Carmo, frei Salvador Santana, escreveu ao rei D. José pedindo confirmação da sentença contra o padre frei Francisco da Conceição, que foi expulso daquela região e condenado ao degredo em Angola. Nota-se que, embora o provincial tivesse decidido por essa sentença, em casos como esse era comum recorrer ao rei pedindo confirmação. Frei Salvador Santana conta que

por innormissimas e reincidentes culpas em que o padre frei Francisco da Conceicao relligiozo daquella vigairaria cahio, de sorte que todas as relligiozas admoestacoens forao innuteis naquelle animo: finalmente pelo mesmo seu Reverendissimo Provincial foy de presente sentenciado a expulsao da mesma Relligião, tirando-se-lhe o habito, e com degredo para o Reyno de Angolla. ${ }^{55}$

\footnotetext{
${ }^{52}$ Ibid.

${ }^{53}$ Ibid.

${ }^{54}$ Ibid.

${ }^{55}$ AHU, CU, CM, doc. 3786.
} 


\section{Pedia a sua majestade que aceitasse}

por em execução o degredo do Padre Frei Francisco da Conceição; porque com effeito esta expulso da nossa Religião, e os seos delictos são de qualidade que necessitam desta demonstração. Na mesma forma sem habito Relligiozo foram mandados para o dito Reyno de Angola outros dous criminozos, chamados Frei Luiz Pantoja e Frei Francisco da Graça com ordens Regias passados ao capitão do Navio. ${ }^{56}$

Aquele século veria, sem dúvida, uma maior vigilância também sobre os membros das ordens religiosas. Isso se justifica por diversas razões. Primeiro, é importante destacar o cenário de profundas mudanças que se vinham processando no Setecentos. A "aceleração da secularização", como bem ajuíza Fernando Catroga, é elemento crucial para entender o período. ${ }^{57}$ Aliados a isso, racionalismo e cientificismo causavam, também, uma boa dose de alterações dos comportamentos em face da religião. As críticas que a Igreja passava a receber certamente que colocavam em xeque o lugar ocupado por ela perante a sociedade. No caso português, a ascensão ao poder de Sebastião José de Carvalho e Melo, que depois se tornaria o marquês de Pombal, acentuou sobremaneira a crise de poder da Igreja. Segundo Zília Osório de Castro, o que foi paulatinamente acontecendo foi uma "subalternização do sagrado" ${ }^{58}$ Já na segunda metade daquele século se veria o rompimento das relações diplomáticas entre Portugal e a Santa Sé, o que uma vez mais confirma a alteração do cenário político-religioso português.

As reformas pombalinas aceleraram o que já vinha acontecendo em certa medida em muitos países da Europa: a afirmação do poder régio na segunda metade do Setecentos. Essa política defendia que os poderes civil e espiritual jamais eram equivalentes e, quando muito, podiam ser pensados apenas como complementares. No reinado de D. José I em Portugal, buscava-se esse fortalecimento da autoridade régia sem deixar de dar a devida importância ao espiritual. Nesse contexto, o jansenismo ${ }^{59}$ teve papel importante na fundamentação das prá-

\footnotetext{
${ }^{56} I d$.

${ }^{57}$ CATROGA, Fernando. Secularização e laicidade. Uma perspectiva histórica e global. Revista de História das Idéias, n. 25, p. 76-77, 2004.

${ }^{58}$ CASTRO, Zília Osório. O regalismo em Portugal. Antonio Pereira de Figueiredo. Cultura História e Filosofia, v. I, p. 360, 1987.

${ }^{59}$ René Taveneaux demonstra o quão complexa pode ser a tarefa de definir o jansenismo. A influência do espaço, dos indivíduos e do tempo faz com que esse conceito seja de difícil enquadramento. $\mathrm{O}$ autor sugere que se opte pelo termo jansenismos, no plural, como o era o movimento. Assim,
} 
ticas regalistas, especialmente porque tratava da especificidade e da independência dos poderes temporal e espiritual, da dessacralização do poder temporal e era carregado de boas doses de oposição ao ultramontanismo, especialmente o inaciano.

O contexto de conflitos entre autoridades seculares e eclesiásticas no bispado maranhense viu seu período mais delicado iniciar-se na década de 1760 . Entre 1761-1778, o sobrinho do próprio marquês de Pombal, Joaquim de Mello e Póvoas, esteve à frente do governo civil. Os conflitos ocorriam porque as autoridades civis envolviam-se em questões que não pertenciam à sua alçada, no que dizia respeito ao julgamento tanto de clérigos regulares e seculares quanto de leigos. Um exemplo disso já foi aqui tratado quando os religiosos carmelitas utilizaram o Juízo da Coroa, tribunal do rei, para manifestar suas insatisfações contra o vigário capitular Dr. Pedro Barbosa Canaes. ${ }^{60}$

O cenário ainda se tornaria mais nebuloso para a Igreja católica e suas diversas ordens religiosas. Foi no governo de Mello e Póvoas que essa autonomia de poder dos juízes seculares ficaria ainda mais evidente, com a criação da Junta das Justiças do Maranhão. Em carta de 1775, Mello e Póvoas descreveu a necessidade de se criar uma Junta das Justiças no Maranhão, mas só em 1777 seu pedido foi atendido, por meio de Carta Régia, ${ }^{61}$ Seu objetivo era solucionar um problema antigo, pois, quando um ministro eclesiástico não obedecia às determinações do Juízo da Coroa, era obrigado a embarcar para Portugal no primeiro navio para resolver a contenda no Desembargo do Paço.

A criação da Junta das Justiças no Maranhão representou, sem dúvida, uma vitória da Justiça secular, que, amparada em um tribunal com maior liberdade para resolver contendas que antes eram enviadas para a Corte, tornou-se um cenário de grandes conflitos com os agentes da Justiça eclesiástica e com mem-

evita-se o risco de uniformização. TAVENEAUX, René. La vie quotidienne des jansénistes aux XVII et XVIII siècles. Paris: Hachette, 1985. p. 9-11. Sobre os primórdios do jansenismo, melhor dizendo, sobre a questão de considerar Jansenius, o bispo católico autor do Augustinus, que teria sido responsável pelo surgimento do jansenismo como um heresiarca, ver SOUZA, Evergton Sales. Jansénisme et réforme de l' Eglise dans l'Empire portugais (1640 à 1790). Paris: Gulbenkian, 2004. p. 40-42.

${ }^{60}$ Neste mesmo artigo, p. 10-11.

${ }^{61}$ ARQUIVO PÚBLICO DO ESTADO DO MARANHÃO. Retratos do Maranhão colonial: correspondências de Joaquim de Mello e Póvoas, governador e capitão-general do Maranhão (1771-1778). São Luís: Secma, 2009. p. 241 e 281, respectivamente. 
bros das mais diversas ordens religiosas. Não que antes esse conflito não existisse, mas a possibilidade de julgar no próprio território maranhense e por ouvidores e agentes régios que diretamente lidavam com os prelados, os eclesiásticos e os superiores dos cenóbios deu tons mais sérios a conflitos que antes demorariam anos para encontrar soluções do outro lado do Atlântico. Acusações de desrespeito e usurpação de jurisdição, feitas por ambas as partes, alimentavam as discussões.

Joaquim de Mello e Póvoas muito frequentemente escrevia para seu tio, o secretário de Estado da Marinha e Ultramar, Francisco Xavier de Mendonça Furtado, dando conta do comportamento dos religiosos do Maranhão. Em uma dessas missivas, respondia ao tio sobre a grande dificuldade de eleger nomes de bons religiosos para receber as prebendas de El Rei. As exigências eram que fossem homens caritativos, mas a falta de caridade, segundo ele, era o mais comum. Disse, por exemplo, que "me não lembro de Eccleziastico nenhum desta terra que me tenha dado provas de não ter este defeito" e que "não hera também menos escandalozo nos mesmos Eccleziásticos a falta de humildade". Apontou apenas um para receber o benefício, frei Antonio da Conceição, vigário dos índios gamelas, já que "das suas mesmas esmollas das Missas está comprando pannos, e ferramentas para dar aos índios". ${ }^{2}$

Em outra carta, sem explicar detalhadamente as razões a Mendonça Furtado, apenas informa que, devido aos maus procedimentos, proibiu frei Antonio dos Remédios de sair do convento de Santo Antônio no ano $1765 .{ }^{63} \mathrm{O}$ dado relevante nesse caso é que a ordem do governante secular foi acatada pelo guardião do convento de Santo Antônio sem qualquer contestação. Novas informações sobre esse caso datam apenas do ano 1772, quando o mesmo guardião do convento, frei Francisco do Sacramento, pediu a real clemência em nome de frei Antonio dos Remédios, que vivia enclausurado desde então. ${ }^{64}$ No mesmo ano, Melo e Póvoas escreveu ao rei para dar seu parecer sobre o caso. Informou que frei Antonio dos Remédios tinha sido levado à Correição pelo ouvidor-geral, e "a devassa que aquele corregedor tirou do Director daquelle lugar, della rezultou mandar Vossa Magestade por avizo da mesma Secretaria de dezaseis de Abril de mil sete-

\footnotetext{
${ }^{62}$ AHU, CU, CM, doc. 4069.

${ }^{63}$ AHU, CU, CM, doc. 4102.

${ }^{64}$ AHU, CU, CM, doc. 4523.
} 
centos e secenta e cinco recluzar a este Relligiozo no seu convento the segunda ordem". Isso porque o frei tinha agredido e descomposto moralmente o principal e sargento-mor do mesmo lugar. Conclui dizendo que, depois de seis ou sete anos de reclusão, o castigo já servira de exemplo aos demais. Aconselhou que, se desejasse, Vossa Majestade poderia se compadecer dele e o aliviar da pena. ${ }^{65}$

Melo e Póvoas, em outra missiva ao tio e secretário da Marinha e Ultramar, descreveu-se muito incomodado com os frades daquela terra no ano 1765. Contou que o provincial do convento dizia já ter conhecimento das transgressões que ele relatava, mas que não tinha tomado providência alguma para punir os culpados. Na carta, ele relatou o seguinte:

V. Ex. Sabe melhor que todos o modo com que vivem os frades nesta terra e por isso não lhe fará novidade o que vou dizer. Constou-me que o prior do Carmo desta Cidade Fr. José de Santa Maria andava amancebado há dezoito anos com uma mulher de quem tinha cinco filhos com escândalo publico. O padre Angello de Santa Brigida que foi prior do Convento da Vila de Santo Antonio de Alcantara o trianno passado e agora morador desta cidade, aonde também estava amancebado com dois ou três filhos tem hum já homem [...] o Pe. Fr. José da Silva Procurador actual deste Convento, também amancebado e com hum filho; e o Pe. Fr. João Loureiro que hera sachristão mor tractava com huma irmã de um Alferes deste Regimento. ${ }^{66}$

Note-se que se tratava de homens importantes dentre o efetivo das ordens religiosas no Maranhão: dois priores e um procurador do convento. Mais adiante, Melo e Póvoas afirmou que o provincial que lá chegou não tratou de punir os culpados, embora reconhecesse a gravidade das transgressões. Desejando ir para o Pará, foi interpelado pelo governador, que dizia "que não hera justo que aquelles frades ficassem no convento, pelo escândalo com que viviam nesta Terra”. ${ }^{67}$ Melo e Póvoas, então, descreveu o desfecho do caso, dizendo que: "logo mandou frei Angello de Santa Brigida e Frei João Loureiro para o Pará, prometendome que o Prior o manda para Tapuitapera, de que não gostei por ficar muito vezinho, pois me parece que merecia maior castigo, e que Frei José da Silva o leva em sua companhia para o Pará”. ${ }^{68}$

\footnotetext{
${ }^{65}$ AHU, CU, CM, doc. 4446.

${ }^{66}$ AHU, CU, CM, doc. 4125.

${ }^{67} \mathrm{Id}$.

${ }^{68}$ Ibid.
} 
Mais adiante, comentou que a razão para tantos desmandos era a negligência dos superiores das referidas ordens. Segundo Melo e Póvoas, a causa de esses frades terem "tão mau procedimento he pela falta de castigo que tem dos seos Prellados; porque se os metessem no cárcere, e lhe impuzessem as penas de sua religião, certamente não haviao de ser tão mao procedidos; ou ao menos não seriam tão escandalosos" ${ }^{69}$ Afirmou que, quando chegou ao Maranhão, "o mesmo que dizem agora dos frades do Carmo, se dezia também dos das Merces”, mas que entrou um comendador na ordem, religioso sério e bem-procedido, que "foy castigando nelles, metendoos no cárcere, levantandolhe os muros; e fechandolhes as portas por onde costumavao sair de noute". Tal comendador teria deixado ainda um desses frades recluso por quatro anos e, com tais medidas, teria recuperado a boa imagem dos mercedários. "Se todos os Prellados fizessem assim", afirma o governador, "estou certo de que se haviao de emendar" ${ }^{70}$

A interferência do governador em assuntos dos religiosos é tão marcante e recorrente que a propalada autonomia que tinham para resolver suas contendas dentro da sua própria ordem perdera totalmente o sentido. $\mathrm{O}$ avanço do regalismo português pode ajudar a explicar esse fato, como já aventei aqui. Exemplo disso é a expulsão de frei Francisco de S. João Nepomuceno no ano 1765. Melo e Póvoas sentencia pelo degredo do frade vigário da freguesia de S. Francisco Xavier de Turiaçu depois de abrir processo contra ele. ${ }^{71}$ Não se destaca o papel do superior do frei Francisco nos autos. A decisão é tomada exclusivamente pelo juízo civil.

Outro exemplo que segue a mesma linha é o processo aberto na Ouvidoria Geral da Correição contra o frei Pedro de Santa Rosa e contra o diretor dos índios da Vila de Guimarães. Joaquim de Melo e Póvoas enviou ofício a Francisco Xavier de Mendonça Furtado informando que mandou abrir processo contra o frade porque ele "castigava os Indios e Indias com palmadas e prizoes, oppondose que o Mestre Escholla ensinasse aos rapazes por querer ser elleso o que tivesse domínio nelles"72 As testemunhas confirmaram nos autos essa queixa. Um deles chegou a afirmar que “...o reverendo padre vigário aos mesmos Indios e

\footnotetext{
${ }^{69}$ Ibid.

${ }^{70}$ Ibid.

${ }^{71}$ AHU, CU, CM, doc. 4111.

${ }^{72}$ AHU, CU, CM, doc. 4061.
} 
Indias os castiga da mesma sorte huns por não saberem a doutrina e outros por algum mau procedimento". Esse frade capucho ainda "teve hum Indio por nome Agostinho prezo mais de quinze dias a qual prizao foy por senão ter desobrigado a Quaresma".73 $\mathrm{O}$ castigo das palmadas, contou outra testemunha, era aplicado "publicamente na Igreja (...) cheya de povo querendo observar". ${ }^{74}$

Novas queixas sobre o comportamento dos religiosos só chegariam ao Reino no ano 1782. O comendador do convento das Mercês, frei José Leite Meirelles, escreveu para a rainha, D. Maria I, sobre a falta de obediência de frei Cipriano dos Santos aos vários comissários que tomaram posse. Contou que o frade religioso conventual das Mercês afirmava ter obtido uma patente de prior-geral dos mercedários na Espanha em que lhe eram concedidas graças e privilégios que eram concedidos aos ex-comissários-gerais. Frei José Leite Meireles afirmou, ainda, que frei Cipriano teria escrito ao Reino "com premissas menos verdadeiras, dizendo tinha governado huanno em Vice Comissario e que tinha servido de Comendador em quatro conventos nesta congregação, sendo somente verdade ter servido esse emprego legitimamente em dois conventos". ${ }^{75} \mathrm{~A}$ ordem régia foi de recolher a tal carta patente à Secretaria de Estado, já que esta não tinha as informações necessárias.

A situação do clero regular à época era das mais delicadas. Em Portugal, por exemplo, José Pedro Paiva aponta para um grande declínio em todas as ordens e congregações a partir do terceiro quartel de Setecentos. Fatores que ajudam a explicar tal fato, segundo ele, são "a crescente laicização dos valores instigada pelas correntes iluministas; a corrupção causada pelos movimentos freiráticos; a alteração no modelo nobiliárquico de colocação de boa parte da descendência secundogênica nos instritos (sic) religiosos" e, ainda, "medidas legislativas tomadas a partir de 1759 por acção de Pombal, algumas delas fortemente lesivas de privilégios até então usufruídos pelo estado clerical". ${ }^{76}$ Também no Maranhão isso ficou visível. Ao menos é isso que faz supor o frei Manoel dos Anjos, provincial de Santo Antônio. Solicitando a vinda de religiosos para o Maranhão no ano

\footnotetext{
${ }^{73} I d$.

${ }^{74}$ Ibid.

${ }^{75}$ AHU, CU, CM, doc. 5417.

${ }^{76}$ PAIVA, José Pedro. "Os mentores”: frades e freiras. In: AZEVEDO, Carlos Moreira (Dir.). História religiosa de Portugal. Lisboa: Círculo de Leitores, 2000. v. II, p. 202.
} 
1784, ele escreveu ao Conselho Ultramarino dando conta de que "no Convento de Santo Antonio da Cidade de S. Luis do Maranhão costumao asestir de vinte e sinco a trinta Religiozos para satisfazer aos officios divinos no Convento; e Servir a varias missões do mesmo Estado", mas naquela época se achavam "somente doze do coro, e hum leigo, todos avançados em idade e oprimidos de moléstias".77

\section{Considerações finais}

José Pedro Paiva afirma que, em Portugal, a situação do clero regular não era das mais brilhantes, e isso deve aplicar-se, também, para o caso do Brasil colonial. Esse estado das coisas, comenta o mesmo autor, "em parte decorria da deficiente formação cultural e da ausência de vocação religiosa de boa parte deste corpo". Assim, era comum encontrar situações de "ausência de observância da regra - os votos de clausura, pobreza e até castidade eram frequentemente quebrados - bem como situações de indisciplina e um nível muito elementar de formação escolar, cultural e até religiosa. ${ }^{78} \mathrm{O}$ que até agora vimos para o caso do Maranhão aponta na mesma direção.

Mesmo com fontes escassas se podem estabelecer algumas conclusões quanto às denúncias e punições a membros de ordens religiosas que transgrediram no Maranhão. Primeiro, a irrisória quantidade de denúncias contra os regulares no Tribunal Episcopal, como mostrado, aponta no sentido da progressiva redução do poder prelatício sobre os membros de ordens, como já aventava o escritor anônimo das Memórias ${ }^{79} \mathrm{O}$ Auditório Eclesiástico do bispado do Maranhão é demonstrativo disso. Julgar clérigos regulares não estava entre as maiores preocupações das autoridades do Juízo Eclesiástico, ou mesmo lhes era colocada uma barreira judicial que proibia de agir nesse sentido. Esse Juízo importou-se mais detidamente com os cura d'almas, os padres seculares e com os leigos que insistentemente desafiavam uma ordem estabelecida que rumava no sentido da reforma dos maus hábitos e no controle jurídico dos infratores.

Segundo, a documentação do Arquivo Ultramarino aponta para um estado de negligência dos próprios superiores das ordens religiosas em julgar seus irmãos

\footnotetext{
${ }^{77}$ AHU, CU, CM, doc. 5554.

${ }^{78}$ PAIVA, 2000, p. 205.

${ }^{79}$ ANTT, Patriarcado de Lisboa, Papéis Diversos, caixa 72, maço 22, doc. sem numeração.
} 
de hábito. Se, por um lado, isso é discutível, visto que não há documentos produzidos pelas próprias ordens que demonstrem que não houve um efetivo controle nem punições, por outro, serve para demonstrar o quão interessadas estavam as autoridades civis em imiscuir-se em assuntos de alçada da Igreja. Isso foi uma prática muito constante, como também foi demonstrado. As penas foram quase sempre rigorosas, como a perda do hábito, a prisão e o degredo. O momento de maior recrudescimento dessa vigilância aos comportamentos dos religiosos não por acaso data do período pombalino, em que, no Maranhão, um sobrinho do próprio marquês de Pombal, Joaquim de Melo e Póvoas, esteve à frente do governo civil. Este estudo objetivava apontar caminhos iniciais para essa questão no Maranhão. Eis um bom campo de estudos em aberto. 